\title{
Research
}

\section{Increased Market Integration, Value, and Ecological Knowledge of Tea Agroforests in the Akha Highlands of Southwest China}

\author{
$\underline{\text { Selena Ahmed }}^{1}, \underline{\text { John R. Stepp }}^{2}, \underline{\text { Robban A. J.Toleno }}^{3}$, and Charles M. Peters $^{1}$
}

\begin{abstract}
This study assesses the persistence and change of traditional land use patterns and ecological knowledge in response to expanded commercialization of tea (Camellia sinensis var. assamica (L.) Kuntze Theaceae in an indigenous Akha (Hani) community in the midlevel montane forests of southwest Yunnan, China. Surveys were conducted in 2005 and 2008, over a period corresponding to a regional tea market boom and bust cycle, to compare the valuation smallholders attribute to land use types and to determine the role that value systems play in shaping environmental behavior and knowledge. At the community level, increased market integration of tea agroforests is associated with reconfiguration of land use, intensified management, reorganization of labor structures, and generation of knowledge on tea resources. Akha have tapped into customary resources and forged new social networks with tea industry agents to take advantage of emerging market opportunities. They have resisted state reforms calling for the cultivation of high-intensity plantations and introduced cultivars. Consequently, they have benefited from price premiums through niche market networks for tea sourced from agroforests and proprietary landraces not available to other communities disempowered by market cycles. Subsistence agriculture, home gardening, and foraging persist for food security despite tea wealth. However, as traditional values are reoriented toward market-based ideologies, the community may risk a breakdown of the social institutions that support sustainability.
\end{abstract}

Key Words: ecological knowledge; land use; natural resource commercialization; social networks; tea (Camellia sinensis)

\section{INTRODUCTION}

The global trend of land use change toward simplification and agricultural intensification is a leading cause of biodiversity loss that threatens ecosystem services and their ability to sustain human welfare (Alcamo and Bennett 2003). Agricultural intensification is a primary concern in centers of crop domestication (Harlan 1975) where human-environment interactions have fostered ecological knowledge and landscape, species, and genetic diversity (Jarvis et al. 2007). As economic incentives, infrastructure, and reforms drive land use intensification, indigenous agroecosystems may provide an effective model for the reconciliation between biodiversity conservation and agriculture (Brush and Meng 1998).

The southwestern Chinese province of Yunnan provides a compelling human ecosystem for examining land use because of its extraordinary biological and cultural diversity that is threatened by dramatic economic and political change (Fox 2009). Yunnan is home to 26 state-designated sociolinguistic groups and at least 18,000 vascular plant species (Li and Walker 1986). Southern Yunnan is in a global biodiversity (Dijk et al. 1999) and biocultural diversity (Stepp et al. 2005) hotspot located between two Vavilov centers of crop domestication (Turrill 1926). It is notable as an ancient crossroads of migration and regional trade between Southeast Asia, India, and Tibet (Yang 2004). Yunnan is also part of the Southeast Asian region recently labeled as 'Zomia' (Schendel 2001) that is characterized by highland cultures that historically fled state organized societies and maintained deliberate stateless structures (Scott 2009).

Over the past 50 years, southern Yunnan has experienced substantial agricultural intensification as subtropical forests and indigenous agriculture 
have transitioned into monoculture systems of tea (Camellia sinensis, Theaceae), rubber (Hevea brasiliensis, Euphorbiaceae), and other cash crops. The proliferation of monocultures has been driven by expanding markets for natural resources coinciding with the opening of China's economy and national development efforts emphasizing modern modes of production. Rubber plantations have replaced approximately 500,000 ha of forest and traditional smallholder agroecosystems in southern Yunnan and neighboring Southeast Asia (Zeigler et al. 2009). Intensified land use in this region is expected to increase to 1.0 - 1.5 million ha by 2050 (Zeigler et al. 2009). Despite the prevalence of monocultures with market expansion, indigenous low-intensity agrarian practices persist in some upland communities, such as tea agroforests.

The present study examines socio-cultural valuation of land use, persistence of indigenous agrarian practices, and ecological knowledge (Hunn 1993, Ellen and Harris 2000, Rocha 2005) of tea varietals in an Akha community in midelevation montane southern Yunnan. Research was conducted over the period 2005 to 2009, corresponding with a tea market boom cycle in Yunnan to assess how land use valuation and ecological knowledge respond to increased market integration. This study provides an understanding of land use decision making from the perspective of rural households as they transform from subsistence economies of regional trade to participants in globalization.

\section{Tea production systems of Yunnan}

Yunnan is the center of diversity of the broad-leaf variety of the tea plant (Camellia sinensis var. assamica (L.) O. Kuntze; Theaceae) and its wild relatives (section Thea of Camellia; Long et al. 1997; Luo et al. 2001). The native tea growing area extends from Yunnan to contiguous parts of China, Laos, Vietnam, Myanmar, and India. Eleven of the twelve wild tea relatives are distributed in the Yunnan-Guizhou Plateau (Ming 1992, Ming and Zhang 1996). Tea cultivation dates over a millennium in southwestern China (Xiao and Li 2002) and it is considered that the $\mathrm{Pu}$, a people ancestral to current-day inhabitants of the region, were its first cultivators (Huang 2005). Many of Yunnan's upland socio-linguistic groups cultivate tea including the Bulang, Wa, De'ang, Lahu, Hani (Akha), Yao, and Jinou. Management history and social exchange of tea, environmental variation, and germplasm introgression have fostered high genetic diversity of tea resources in Yunnan (Xiao and $\mathrm{Li}$ 2002, Chen et al. 2005).

This study focuses on a community that manages tea in agroforests. Tea also grows in other systems, which along with agroforests can be classified along a continuum of agricultural intensification: forestsagro-forests-mixed crop fields-terrace plantations (Ahmed et al. 2010). Forest tea populations are tea trees that are wild, sparsely planted in mixed forests, or cultivated trees that have become feral. Tea trees may grow to $15 \mathrm{~m}$ or higher and live for over one hundred years in a forest environment (Xiao and $\mathrm{Li}$ 2002). Tea agroforests, or 'ancient forest tea gardens' / gushu cha yuan, are forest areas (0.5 $3.0 \mathrm{ha}$ ) thinned for tea cultivation or swidden areas where plants are regenerated to create a multistoried vegetative structure, i.e. high canopy level, midlevel tree layer, and herbaceous ground layer (Long and Wang 1996). Tea trees in agroforests are generally pruned to spread their branching formation and are maintained between 2 to $8 \mathrm{~m}$. The vegetative structure and composition of agroforests mimic some of the ecosystem services provided by forests including soil fertility, watershed, and pests and disease control. Long and Wang (1996) inventoried 283 species of higher plants in a Jinuo tea agroforest, including edible, medicinal, and timber species. Mixed crop tea plots are created in tea agroforests by replacing associated woody plants with grain production. Tea trees are intensively pruned to increase sun exposure for heightened yields. Historically, some smallholders cyclically transitioned tea agroecosystems between forests, agroforests, and mixed crop plots (Figure 1).

Terrace tea plantations, i.e., taidi cha or 'terrace tea', are part of the agricultural-intensive monocultures that have gradually replaced Yunnan's lowintensity agroecosystems with economic and political reforms. Since the 1970s, state-supported extension agents have trained rural smallholders on 'improved' tea cultivation based on uniformity, high-yield, and efficiency by planting clonal propagules in compact rows and pruning them to waist-high shrubs. In most instances, terrace tea plantations rely on chemical input for management of soil fertility, pests, and disease because they lack the structure and function of biodiverse forests to provide these ecosystem services. Poor tea production practices sometimes lead to commercial teas with pesticide and heavy metal contamination, which have adverse implications for human heath (Qin and Chen 2007). 
Fig. 1. Cyclical nature of traditional tea production systems in southern Yunnan between forest, agroforest, and mixed-crop plots.

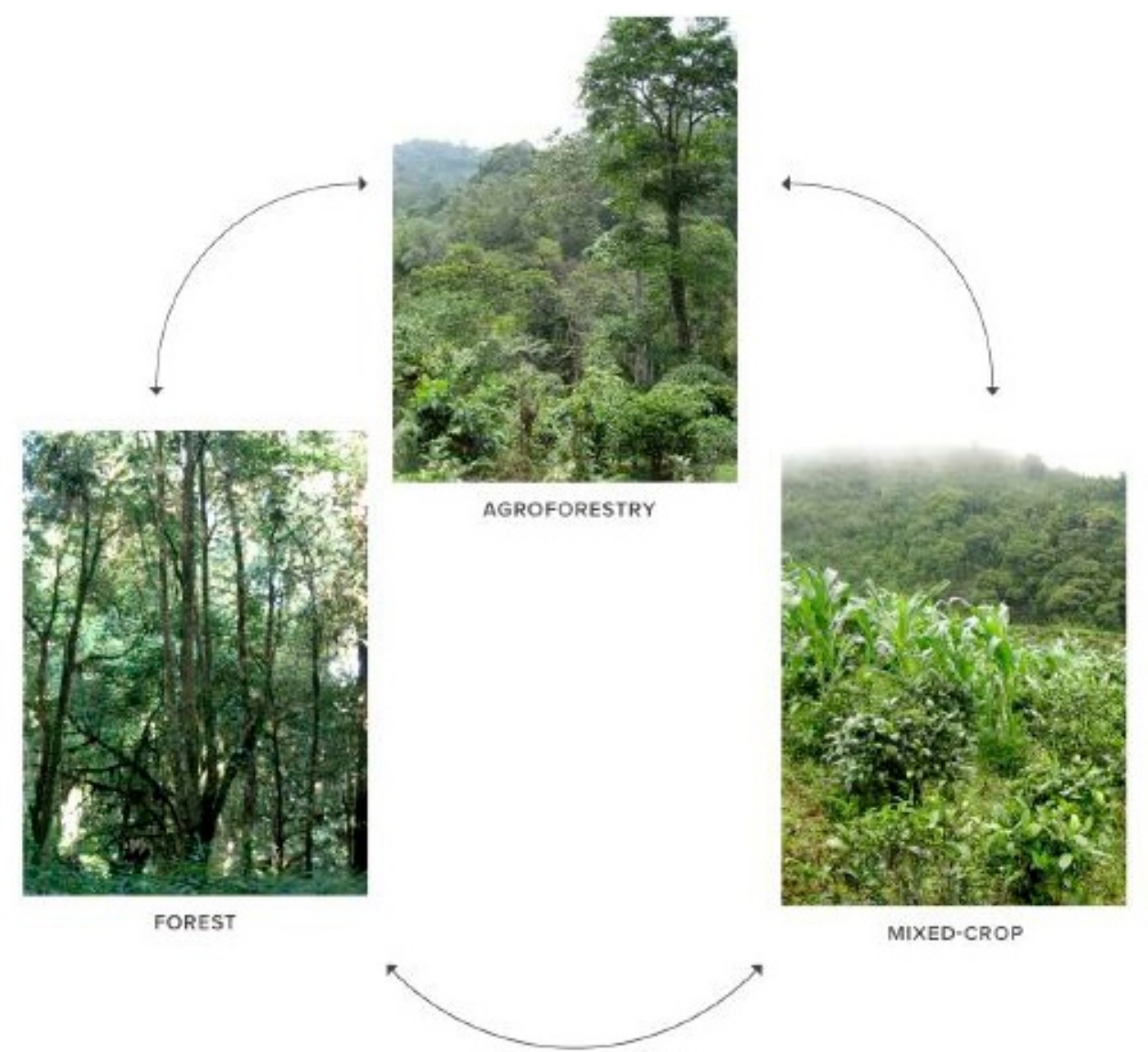

The Chinese state recently strengthened incentives for planting terrace tea plantations with the implementation of the Grain for Green campaign that was piloted in 1999 to increase forest cover and prevent soil erosion on sloped cropland ( $\mathrm{Xu}$ et al. 2006). Smallholders were offered grain subsidies in exchange for replacing grain fields with permanent cash cropping classified as forest or 'green cover.' Rubber and tea plantations fit as 'green cover' and have been extensively promoted since 2002-2003 to replace swidden agriculture in southern Yunnan because they conform to the state's dual environmental and development priorities (Sturgeon 2005, Fox 2009). These environmental priorities stem from the state's response to the Yangtze River flood damage in 1998 and attribution of blame to farmer practices; the state consequently reclaimed forests from communities and discouraged swidden cultivation (Sturgeon 2007). The state has additionally encouraged private enterprises to cultivate terrace tea plantations in southern Yunnan by facilitating the sublease of land previously managed as swidden areas by upland communities.

\section{Market integration of tea resources}

Tea developed as a key commodity by the Ming Dynasty (1368-1644) between Yunnan and Tibet on the Cha ma dao (Tea-Horse Road), a trade route part of the caravan network (Xi'nan sichouzhilu / Southwest Silk Road) connecting Southwest China, Tibet, Southeast Asia, and south Asia (Yang 2004). During the Qing Dynasty (1644-1912), districts such as the 'Six Great Tea Mountains' (Liu da cha shan) of Sipsongpanna (Xishuangbanna) were promoted because of their excellent tea-growing environment. The tea trade in southern Yunnan 
appears to have increased until around the time of the War of Resistance (1937-45) against the Japanese (Hill 1998). With the establishment of the People's Republic of China in 1949, the state promoted tea production by developing tea factories, research institutes, and demarcation of tea districts.

Yunnan's tea products experienced heightened market integration during a recent boom cycle (2002 - 2008) when producers and traders revitalized and reimagined Yunnan's longstanding tea trade, bringing it up-to-date with the sensibilities and desires of modern consumers. This boom was a response to China's emerging free market economy and state promotion of tea (Sturgeon 2005). Toleno (2006) suggests that this boom was further a consequence of demand from tea consumers in China, Taiwan, Singapore, Hong Kong, Japan, and Korea in response to rising health concerns and taste attributes of tea contaminated with chemical residue. Several studies between 1998 and 2005 found Chinese tea samples contained agricultural chemical residues and heavy metal in excess of safety standards (Wang 2005, Han et al. 2006). Reports noted rising anxiety by consumers who feared death by acute poisoning and health issues from chronic poisoning by contaminated foodstuffs (Jiang 2003). Yunnan's tea producers and traders met the market opportunity presented by such studies with efforts to distinguish their tea from other areas. They branded origin, authenticity, culture, history, ecology, health, and vintage in marketing processed leaves of the broad-leaf variety of the tea plant under the names pu'er (or pu-erh) and sheng tai cha ('ecological tea' or 'natural tea').

Increased demand for pu'er and 'ecological tea,' followed by hype by consumers in Asia, spurred a bull market for tea from Yunnan. As prices escalated, income of producers and traders increased over 100-fold and new actors entered the supply chain. Tea production communities witnessed the return of off-farm laborers. Tea terraces became a dominant land use and products from these plantations were often falsely represented as sourced from 'ecological' systems such as agroforests. Industrial processors took advantage of fermentation technologies to impart the smooth taste characteristics of aged $p u$ 'er, which allowed some unscrupulous processors to misrepresent production dates. A short-term focus and the lack of regulatory frameworks compromised the quality of Yunnan's tea production. A study at the peak of the pu'er boom found that Yunnan ranked second out of Chinese provinces in greatest lead concentration in tea samples (Qin and Chen 2007). Consumer knowledge of adulteration and oversupply of low-quality tea led to the market collapse. Producers experienced variable repercussions. Communities that converted their lands to tea terraces struggled to fulfill subsistence needs while those that maintained 'ecological' or organic tea production and innovated with processing were afforded a competitive market edge (Menzies 2008).

\section{DESCRIPTION OF STUDY AREA}

Research was conducted in Baljalpuxeevq, a smallholder Akha community in the Bulang Mountains, Menghai County, Xishuangbanna Dai Autonomous Prefecture, Yunnan, China (Figure 2). Baljalpuxeevq is in the border area near Myanmar at 1800 meters in evergreen broadleaf montane forest within the Indo-Burma biodiversity hotspot (Dijk et al. 1999). The Akha belong to a branch of the Tibeto-Burmese socio-linguistic family who migrated from the Qinghai-Tibetan Plateau to the Mekong River Region of Xishuangbanna, Myanmar, Laos, and Thailand (Alting von Geusau 2000). They are closely related to the Hani of the Red River area of Yunnan and northern Vietnam (Alting von Geusau 2000) and are officially grouped as Hani in China. Historically, the Han Chinese considered the Akha to be Wuman, an ethnonym denoting non-Sinicized "barbarians" with whom they were at times in conflict (Alting von Geusau 2003).

Baljalpuxeevq was chosen as a study site for its remote location that historically limited interaction with the market and state compared with many other communities in Xishuangbanna. The tea trade in Xishuangbanna began primarily in areas to the northeast of the Mekong River because of greater accessibility than communities to the southwest of the Mekong River (Hill 1998) such as Baljalpuxeevq. During the early 20th century, Baljalpuxeevq's inhabitants traded opium and tea for salt and rice with Tai (Tai-Lue or Dai) in Myanmar and occasionally in Xishuangbanna's lowlands, but its remote location limited trade. Even after Menghai, to the southwest of the Mekong, developed as a tea-processing center, Baljalpuxeevq was slower to expand its tea trade than other more accessible areas (Toleno 2006). The study site's 
Fig. 2. Study site in the Bulang Mountains, Menghai County, Xishuangbanna Dai Autonomous Prefecture, Yunnan, China.

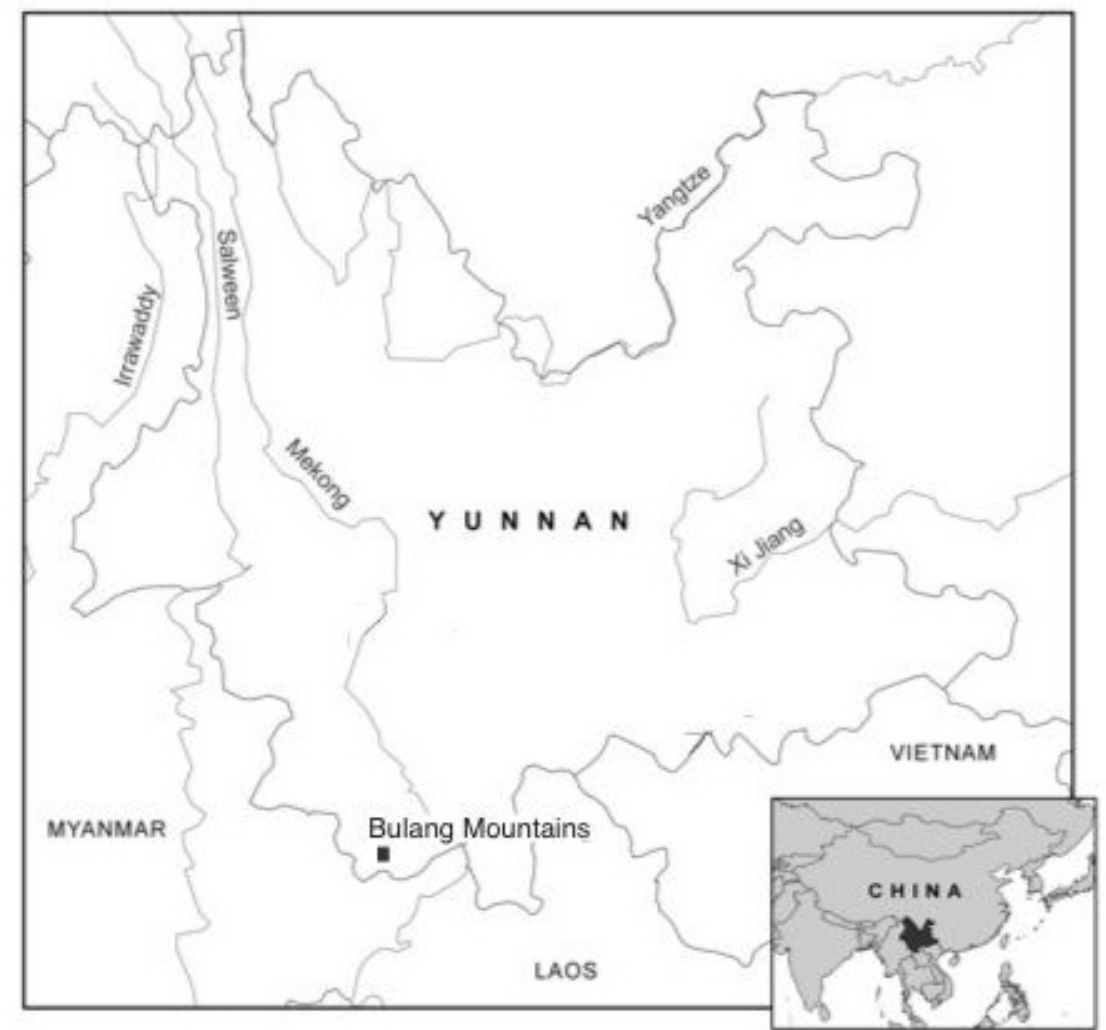

midlevel montane location above the altitude where rubber can grow $(1,100 \mathrm{~m})$ allowed it to avoid statepromoted rubber projects. However, with the recent tea boom, Baljalpuxeevq's agroforests have become one of the most sought after sources for 'ecological' pu'er.

In 2008, 427 Akha inhabited Baljalpuxeevq in family units of 88 households. The Akha arrived in the Bulang Mountains in the mid-19th century from a nearby area. The Bulang previously inhabited Baljalpuxeevq. They created and managed many of the agroecosystems that the Akha now steward, including tea agroforests. Local households are organized in a nuclear structure with a portfolio of land use surrounding the settlement. The nearest market town is six hours by foot or 1.5 hours by automobile (45 kilometers) on unpaved roads developed by the state in the 1960s. Historically, agriculture was predominantly based on swidden cultivation where forests were cleared for crop production and then regenerated back into forests during a fallow period to replenish soil fertility. Agricultural land was communally managed in Baljalpuxeevq during China's collective period (1958-1982). New state demarcations were imposed following policy reforms of 1982-1983 when communal agricultural and forest lands were distributed to households under the liangshanyidi policy, as in other rural communities in the region (Xu et al. 1999). Current land tenure combines locals systems negotiated with state policy. Sections of forestlands are demarcated as household, community, and state forest. Since 2006, the provincial government has facilitated commercial tea enterprises to sublease land from communities in the Bulang Mountains previously managed for swidden cultivation for the creation of terrace tea plantations. These enterprises hire migrant workers and have created laborer settlements in land contracted from Baljalpuxeevq and neighboring communities. 


\section{METHODS}

Land use valuation and agroecological knowledge surveys were conducted in 2008 to understand variability of values and knowledge within the community and how these dimensions are responding to increased market integration. Land use results were compared with 2005 data collected by Toleno (2006). Agroecological knowledge surveys were adapted from Rocha (2005) to understand the variability of folk taxonomy of tea varietals. Surveys started with free listing interviews (Weller and Romney 1988) to define the domains 'types of land use' and 'types of tea' around the community. Fifteen households were randomly selected for free listing interviews of land use types and 30 households were selected for free listing interviews of tea types. Informants were asked about all the types of land use and tea in the community. This was supplemented with informant walks around the community and open-ended interviews. Land use categories were photographed and names were recorded in Akha, Mandarin, and English. The most frequently reported land uses were incorporated in weighted ranking valuation interviews. Expert informants were selected to identify tea types for use in specimen sorting interviews to measure agroecological knowledge.

Thirty informants of equal age classes from 22 households were randomly selected to rank land use photographs. Age classes were set as youngest generation $(<35$ years old $)$, middle aged $(35-50$ years old), and elders ( $>50$ years old). Informants were requested to score photographs with a set of 100 markers to indicate the relative importance of each land use category based on personal meanings of importance. Semistructured interviews followed to understand ranking schemata and informants' personal meanings of importance. Thirty additional informants of equal age and gender groups were selected to sort tea types. Informants were presented with a pile of specimens and requested to sort (Weller and Romney 1988), name, and describe the samples and share their preferences.

The number of markers assigned to each land use was expressed as a Land Use Importance Value (LIV) percentage and the number of tea types linguistically marked by each informant relative to total tea types was expressed as an Ecological Knowledge Score (EKS). A coded-valuation schemata modified from Kellert and Wilson (1993) was applied to informant responses. Bivariate regression, analysis of variance, means comparisons using Tukey-Kramer HSD, and principal components analysis were employed to assess consensus and variation of LIVs and EKSs among age and gender groups.

\section{RESULTS}

\section{Survey of farmers' land use valuation}

Research conducted in 2005 during the early phase of the Yunnan tea boom documented 34 land use categories (Table 1; Toleno 2006). Wet rice paddy, upland dry rice fields, and wet rice terraces were the three most significant land use categories based on informant consensus. Since 2005, local Akha have stopped managing upland dry rice fields and upland wet rice terraces in response to state discouragement of shifting cultivation and opportunities presented by tea markets. Other significant land uses in 2005 included tea fields (tea agroforests), cardamom plantings (cal kol yal / Amomum tsaoko; Zingiberaceae), pastures, schools, corn fields, sweet bamboo stands, and peanut fields. Research conducted in 2008 following the peak of the Yunnan tea boom documented 29 land uses with 14 significant categories. Table 1 compares land uses reported by informants between the 2005 and 2008 study periods. Old tea agroforests, wet rice paddy, and forests were the most important land uses in 2008 (Table 2) and are the primary contributors of household income, dietary subsistence, and other natural resources. Informants report that they choose to manage wet rice paddy over their customary upland rice because the labor demands are seasonal rather than constant throughout the year. Banana stand, fallow, grazing fields, and tobacco plots were the least valued land uses.

Locals have expanded tea cultivation area for future generations and intensified management of existing tea agroforests to increase production. From 1984 to 2009 , total tea cultivation area managed by Baljalpuxeevq's Akha expanded from 267 ha to 467 ha by planting tea in forests and swidden fields. Smallholders have intensified management in existing tea agroforests through selective girdling of associated woody plant species to cultivate more tea. Intensification of tea agroforests has thinned canopy, increased sunlight, and stimulated the growth of invasive weedy species. At the same time, locals are transforming some swidden fields previously managed for upland rice into tea 
Table 1. Comparison of land use categories documented during 2005 and 2008 data collection periods in Buljalpuxveeq.

\begin{tabular}{|c|c|c|c|}
\hline \multicolumn{2}{|c|}{ Land Use Categories } & \multicolumn{2}{|c|}{ Year Documented } \\
\hline & & 2005 & 2008 \\
\hline Al baol dev mil caq & A type of forest & $\mathrm{x}$ & $\mathrm{x}$ \\
\hline Al du yal & Corn field / mixed crop land & $\mathrm{x}$ & $\mathrm{x}$ \\
\hline Al haq yal & Type of bamboo stand & $\mathrm{x}$ & $\mathrm{x}$ \\
\hline Al siq yal & Fruit orchard & $\mathrm{x}$ & $\mathrm{x}$ \\
\hline Cal kol yal & Cardamon (Amomum tsako) land & $\mathrm{x}$ & $\mathrm{x}$ \\
\hline Dal hml / al neiq yal / ha qil yal & Rattan stand & $\mathrm{x}$ & $\mathrm{x}$ \\
\hline Dei ma & Wet rice paddy & $\mathrm{x}$ & $\mathrm{x}$ \\
\hline Haq geeq yal & Type of bamboo thicket & $\mathrm{x}$ & $\mathrm{x}$ \\
\hline Hhaoq niyul yal (1) & Seasonal forest vegetable garden & $\mathrm{x}$ & $\mathrm{x}$ \\
\hline Hhaoq niyul yal (2) & Home vegetable garden & $\mathrm{x}$ & $\mathrm{x}$ \\
\hline Jiefang cao (Mandarin) & Ageratina adenophora / weed fields & $\mathrm{x}$ & $\mathrm{x}$ \\
\hline Laol baoq yul & Old tea field / tea agro-forest & $\mathrm{x}$ & $\mathrm{x}$ \\
\hline Laol baoq xeevq & New tea field / new tea agro-forest & $\mathrm{x}$ & $\mathrm{x}$ \\
\hline Li hhei (yal saq) / dal piav yal & New fallow / barren or bracken land & $\mathrm{x}$ & $\mathrm{x}$ \\
\hline Mal dao xeel & Canna edulis / Bajiaoyu plot & $\mathrm{x}$ & $\mathrm{x}$ \\
\hline Neev paoq yal & Peanut field & $\mathrm{x}$ & $\mathrm{x}$ \\
\hline Neev piav yal / al neev yal & Soybean / bean field & $\mathrm{x}$ & $\mathrm{x}$ \\
\hline Nga beiv yal & Banana stand & $\mathrm{x}$ & $\mathrm{x}$ \\
\hline Nioq hyuv / dal deq yal / li hhei (yal saq) & Grazing pasture & $\mathrm{x}$ & $\mathrm{x}$ \\
\hline Saoq hav / al baol saoq hav & Old forest / dense forest area & $\mathrm{x}$ & $\mathrm{x}$ \\
\hline Ssavq peel yal & Type of bamboo stand & $\mathrm{x}$ & $\mathrm{x}$ \\
\hline Uq jil yal & Thatch grass field / type of fallow & $\mathrm{x}$ & $\mathrm{x}$ \\
\hline Ya haoq yal & Tobacco land & $\mathrm{x}$ & $\mathrm{x}$ \\
\hline Yao ssavq yeiq mil caq & Unfrequented place (Watershed forest) & $\mathrm{x}$ & $\mathrm{x}$ \\
\hline Yaq il yal & Potato land & $\mathrm{x}$ & $\mathrm{x}$ \\
\hline Ziq yal / yuf maf yal & Hemp field & $\mathrm{x}$ & \\
\hline Qeil yal & Upland dry-rice field & $\mathrm{x}$ & \\
\hline
\end{tabular}




\author{
Dei ma do siq \\ Mal dei yal \\ Xuexiao (Mandarin) \\ $\mathrm{Meq}$ \\ Lav beeq pu \\ Laol baq \\ Saq soq yal \\ Diq xeel (jaoq) \\ Hhavq laoq / il quvq \\ Paol qeil yal \\ Saq keq \\ Guoyou [senlin] (Mandarin) \\ Fengjing lin (Mandarin) \\ Gaoq jaoq hhal \\ Jiti lin (Mandarin)
}

Wet rice cultivated in a hillside terrace
Pumpkin patch
The village school
Lowlands (not local land use)
Han village (not local land use)
River or stream (as food source)
Mountain pine (not local land use)
Where things do not grow well
Narrow valley floor with standing water
Sugarcane fields (not local land use)
Land where trees are returning
State forest
View forest
Burial forest
Collective forest

$\mathrm{X}$

$\mathrm{X}$

$\mathrm{X}$

$\mathrm{X}$

$\mathrm{X}$

$\mathrm{X}$

$\mathrm{X}$

$\mathrm{X}$

$\mathrm{X}$

$\mathrm{X}$

$\mathrm{X}$

$\mathrm{X}$

$\mathrm{X}$

$\mathrm{X}$ agroforests. Thus, although plant biomass decreases in forests and agroforests, it is being enhanced in previously active swidden areas that are being transformed to tea agroforests.

Tea production has changed from being an occasional activity for women to a key livelihood for the entire adult community. Before the 1980s, locals intermittently visited their agroforests to harvest tealeaf. With the increased market value of agroforest tea, local Akha have restructured their livelihood activities to dedicate five to six days per week from the start of the spring harvest in March through the end of the fall harvest in October. Baljalpuxeevq's middle-aged men have tapped into customary resources and developed social networks with tea industry agents to take advantage of market opportunities. These customary resources include local institutions of natural resource management and associated ecological knowledge, experience with self-organization, and experimentation with plants and land use. Locals have also started a community group adapted from customary institutions to unite individual household management, processing, and marketing of tea toward creating brand recognition for the community. This new resource institution functions to ensure production without agrochemicals, set a minimum price, prohibit tea grown outside the community from being sold in the village, share knowledge, and experiment with tea processing. The group has refined tea processing techniques to better preserve taste and have revived products such as pressed tea in bamboo.

Income received by local farmers for agroforest tea has increased from USD \$1.18 per kilo of dried leaf in 2000 to a high of USD \$220 per kilo. Tea contributes to $99 \%$ of household cash income and has replaced cardamom (Amomum tsako; Zingiberaceae), introduced to the community in 1987 , as the primary source of income. Annual tea income varies depending on household size and social networks. Despite the collapse of the regional pu'er market, connoisseurs remain willing to pay premiums for high-quality product from Baljalpuxeevq's old agroforests. With this new wealth, many local households have moved from below the poverty line to middle-class entrepreneurs. They have utilized profits from tea sales for household items such as vehicles, meat, clothes, snack foods, and electronic products. They have also used profits for building 
Table 2. Mean Land use Importance Values (LIVs) by informant gender and age-class elicited in Buljalpuxeevq in 2008.

\begin{tabular}{|c|c|c|c|c|c|c|}
\hline LAND USE CATEGORIES & $\begin{array}{l}\text { LIV Mean } \\
\text { Total }\end{array}$ & $\begin{array}{l}\text { LIV Mean } \\
\text { Male }\end{array}$ & $\begin{array}{l}\text { LIV Mean } \\
\text { Female }\end{array}$ & $\begin{array}{l}\text { LIV Mean } \\
\text { Ages < } 35 \\
\text { Years }\end{array}$ & $\begin{array}{c}\text { LIV Mean } \\
\text { Ages } 35-49 \\
\text { Years }\end{array}$ & $\begin{array}{l}\text { LIV Mean } \\
\text { Ages }>50\end{array}$ \\
\hline 1. Old tea field / tea agro-forest & $11.91 \%$ & $12.05 \%$ & $11.68 \%$ & $12.67 \%$ & $12.51 \%$ & $10.81 \%$ \\
\hline 2. Wet rice paddy & $11.47 \%$ & $11.52 \%$ & $11.38 \%$ & $11.31 \%$ & $11.14 \%$ & $11.85 \%$ \\
\hline $\begin{array}{l}\text { 3. Forest (national \& community } \\
\text { forest) }\end{array}$ & $11.13 \%$ & $11.31 \%$ & $10.84 \%$ & $10.47 \%$ & $11.49 \%$ & $11.31 \%$ \\
\hline $\begin{array}{l}\text { 4. New tea field / new tea agro- } \\
\text { forest }\end{array}$ & $9.56 \%$ & $9.92 \%$ & $8.96 \%$ & $9.97 \%$ & $10.42 \%$ & $8.68 \%$ \\
\hline 5. Home vegetable garden & $7.84 \%$ & $7.92 \%$ & $7.71 \%$ & $8.77 \%$ & $8.26 \%$ & $6.72 \%$ \\
\hline $\begin{array}{l}\text { 6. Cardamom (Amomum tsako) } \\
\text { land }\end{array}$ & $7.51 \%$ & $7.51 \%$ & $7.50 \%$ & $6.90 \%$ & $7.98 \%$ & $7.81 \%$ \\
\hline 7. Corn field / mixed crop land & $6.54 \%$ & $6.37 \%$ & $6.83 \%$ & $6.54 \%$ & $6.48 \%$ & $6.68 \%$ \\
\hline 8. Rattan stand & $6.53 \%$ & $6.98 \%$ & $5.76 \%$ & $6.22 \%$ & $6.45 \%$ & $6.64 \%$ \\
\hline 9. Bamboo stand & $6.17 \%$ & $5.80 \%$ & $6.79 \%$ & $6.28 \%$ & $5.06 \%$ & $6.67 \%$ \\
\hline $\begin{array}{l}\text { 10. Seasonal forest vegetable } \\
\text { garden }\end{array}$ & $5.62 \%$ & $5.71 \%$ & $5.46 \%$ & $4.85 \%$ & $5.73 \%$ & $6.40 \%$ \\
\hline 11. Banana stand & $4.64 \%$ & $3.67 \%$ & $6.31 \%$ & $4.74 \%$ & $4.06 \%$ & $5.34 \%$ \\
\hline $\begin{array}{l}\text { 12. New fallow / barren or } \\
\text { bracken land }\end{array}$ & $4.05 \%$ & $4.06 \%$ & $4.03 \%$ & $4.36 \%$ & $3.81 \%$ & $3.93 \%$ \\
\hline 13. Grazing pasture & $3.77 \%$ & $3.63 \%$ & $3.99 \%$ & $5.16 \%$ & $2.77 \%$ & $3.28 \%$ \\
\hline 14. Tobacco land & $3.26 \%$ & $3.56 \%$ & $2.75 \%$ & $1.76 \%$ & $3.85 \%$ & $3.87 \%$ \\
\hline
\end{tabular}

new homes, roads, and community facilities. In addition, income from tea is used for hiring external labor for harvesting tea and for construction. This is the first time that Baljalpuxeevq's Akha have employed external labor, including members of the historically dominant Dai socio-linguistic group.

Despite recent tea wealth, locals continue to rely on subsistence agriculture, home gardening, and foraging as risk management and because of restricted accessibility to lowland markets during the rainy season. In addition, they continue subsistence farming because of preferences for locally grown food. Informants emphasize that the tea market is unpredictable and they should not abandon other farming activities. Coded land use valuation (Table 3 ) suggests that local Akha have a multidimensional value system. Value attributed to unutilized land for its past and potential use highlights a long-term perspective. In view of the greater proportion of subsistence values attributed to land uses by elder informants vs. the middle and youngest generations, it appears that land value systems are being reoriented toward a cash economy.

Bivariate fit analysis of Land Use Importance Values (LIVs) by informant age further supports 
Table 3. Coded valuation schemata of the proportion of informants that indicated a particular value orientation toward land use categories.

\begin{tabular}{|c|c|c|c|c|c|c|c|c|c|c|c|c|c|}
\hline LAND USE CATEGORIES & Holistic & Spiritual & Traditional & $\begin{array}{c}\text { Survival } \\
\text { Skills }\end{array}$ & Moralistic & $\begin{array}{c}\text { Abstract } \\
\text { Liking }\end{array}$ & Utility & Income & Ecological & Health & Social & Aesthetic & $\begin{array}{l}\text { Destructive } \\
\text { - Negative } \\
\text { Value }\end{array}$ \\
\hline Old tea field / tea agro-forest & $3 \%$ & $3 \%$ & $14 \%$ & - & - & $14 \%$ & $3 \%$ & $50 \%$ & - & $8 \%$ & $6 \%$ & - & - \\
\hline Rice paddy & - & - & $16 \%$ & $25 \%$ & - & $9 \%$ & $36 \%$ & - & $9 \%$ & $9 \%$ & - & - & - \\
\hline Forest & $24 \%$ & $5 \%$ & $12 \%$ & - & $3 \%$ & $1 \%$ & $26 \%$ & $8 \%$ & $24 \%$ & $4 \%$ & $2 \%$ & $6 \%$ & - \\
\hline New tea field / tea agro-forest & $8 \%$ & - & $25 \%$ & - & $8 \%$ & $8 \%$ & - & $33 \%$ & - & - & - & - & - \\
\hline Home vegetable garden & $14 \%$ & - & - & - & - & - & $71 \%$ & - & - & $14 \%$ & - & - & - \\
\hline $\begin{array}{l}\text { Cardamon (Amomum tsako) } \\
\text { land }\end{array}$ & - & - & - & - & - & - & - & $64 \%$ & $9 \%$ & $27 \%$ & - & - & - \\
\hline Corn field / mixed crop land & - & - & - & - & - & $14 \%$ & $43 \%$ & - & - & - & - & - & $43 \%$ \\
\hline Rattan stand & $17 \%$ & - & $6 \%$ & $6 \%$ & - & $11 \%$ & $28 \%$ & - & $11 \%$ & - & $22 \%$ & - & - \\
\hline Bamboo stand & $16 \%$ & - & - & - & - & - & $83 \%$ & - & - & - & - & - & - \\
\hline Seasonal forest vegetable garden & - & - & - & - & - & - & $50 \%$ & - & - & - & - & - & $50 \%$ \\
\hline Banana stand & - & - & - & - & - & $57 \%$ & $29 \%$ & - & $14 \%$ & - & - & - & - \\
\hline $\begin{array}{l}\text { New fallow / barren or bracken } \\
\text { land }\end{array}$ & $32 \%$ & - & $5 \%$ & $5 \%$ & $5 \%$ & & $16 \%$ & $5 \%$ & $32 \%$ & - & - & - & - \\
\hline Grazing pasture & $8 \%$ & - & $46 \%$ & - & - & $8 \%$ & $31 \%$ & - & - & - & - & $8 \%$ & - \\
\hline Tobacco land & - & - & - & - & - & - & $33 \%$ & - & - & - & $50 \%$ & - & $17 \%$ \\
\hline
\end{tabular}

reorientation of local valuation systems toward market economics. An increase in informant age is significantly associated with increasing valuation of wet rice paddy $(P<.0001)$, ginger plots $(P$ $<.0001)$, corn / mixed-crop land $(P<.0001)$, rattan stand $(P<.0004)$, bamboo stand $(P<.0001)$, forest vegetable garden $(P<.0060)$, and banana stand $(P$ $<.0132)$. With the exception of cardamom plots, these land uses represent subsistence strategies. An increase in informant age is significantly associated with a trend of decreasing valuation of tea agroforests, forest, home gardens, fallow, and pastures. Home gardens are a relatively new land use in the community, and forests are increasingly perceived as a limited resource.

Principle-components analysis (PCA) of land use valuation matrices suggests variability in the community among gender and age. PCA found the first eigenvalue to account for $24.34 \%$ of variance for total value ranking schemes. Results of gender and age-class comparisons support that within- group agreement is greater than total group agreement. The first eigenvalue accounts for $32 \%$ of variance among female land use schemata, $26 \%$ for males, $41 \%$ for the youngest generation, $30 \%$ for the middle-aged, and $36 \%$ for the eldest.

Other land use changes over the study period since 2005 are that buffalo are no longer in pastures and that some land previously managed for swidden cultivation has been subleased to private tea enterprises through state facilitation. The decision to no longer raise buffalo is a function of state policy discouraging pasture management because of the potential for environmental degradation and because motorized tractors have replaced buffalo for plowing fields. Local diets increasingly include meat purchased from lowland markets. Lands previously managed as pasture are valued for their potential to be transferred to other uses with increasing concerns of land shortage. This concern has risen as new policies prohibit resettlement, the population grows, and outside commercial 
enterprises sublease land that was previously managed by locals for swidden cultivation.

\section{Agroecological knowledge surveys of tea varietals}

Results suggest that local Akha maintain diverse tea varietals, i.e., types or landraces, in agroforests because of varying personal preferences and as risk management. Social exchange and experimentation of plant germplasm are customary practice in Baljalpuxeevq while discernment of tea varietals has become more rigorous in response to increased market integration and value of tea. Locals source tea germplasm from surrounding forests, other communities, and occasionally experiment with cultivars introduced by extension agents. Lowland tea varietals are generally considered unsuitable for upland environments and vice versa.

Local tea classification includes 3 to 15 tea varietals discerned based on leaf characteristics, i.e., color, shape, texture, thickness; taste, i.e., bitter, bitter with a sweet aftertaste, sweet, sour, salty, acrid; type of production system, i.e., agroforest, forest, terrace; ecological attributes, i.e., shade cover, soil types, associated woody species; origin, i.e., local vs. introduced; tree form and yield. Origin is the primary character used in selecting tea varietals, which locals differentiate as 'Akha people's tea' vs. 'Han terrace tea'. Leaf color and size are the key characters in local tea nomenclature. Pavq mngl laol baoq ('long leaf tea'), pavq qavl laol baoq ('slender leaf tea'), laol baoq bawneh ('red tea'), and Han taidi cha ('Han terrace tea') have the greatest agreement between informants' classification schemes. The former two types are more broadly classified as 'Akha people's tea'. Figure 3 shows an example of local tea classification.

Local tea types have the greatest frequency in the community's tea agroforests and are preferred by all informants while state-introduced cultivars occur in lowest frequency and are least preferred. The oldest tea agroforests, over 70 years old, are dominated by two local tea varietals and middleaged tea agroforests consist of four to fourteen tea varietals and a mean of seven. Only a few individuals of introduced cultivars are found in tea agroforests, but comprise $100 \%$ of systems created under the state's Grain for Green campaign. Forty percent of informants participate in this program by managing terrace tea on previous swidden land in exchange for grain subsidies. However, locals generally do not harvest this tea because of its perceived undesirable taste and because they allocate their limited labor to more profitable tea agroforests.

Ecological Knowledge Scores (EKS) indicate that knowledge of tea resources is increasing with expanded market integration and is shifting from women to men. Middle-aged men responded to the increased value of tea by utilizing traditional agroecological knowledge, increasing interaction with tea resources, and enhancing linguistic discernment of tea types. This has been facilitated through social networks within the community, nearby communities, and with tea industry agents. Middle-aged men hold the greatest knowledge of tea types (91\% EKS) followed by younger-aged men (67\% EKS), elder-aged women (63\% EKS), younger-aged women ( $60 \% \mathrm{EKS})$, and middle-aged women (53\% EKS). Elder-aged men have the lowest ability to discern tea types (27\% EKS). Consequently, bivariate analysis of EKS by informant age illustrates a significant trend of decreasing ability to identify tea types with an increase in age $(P<0.0001)$. Comparison of EKSs indicates that the variation between age groups is significant $(P<0.0171)$ as well as between males and females of the middle-aged group $(P<0.0002)$ and the eldest group $(P<0.0001)$. Principal Component Analysis of sorting schemata demonstrates that there is not complete cultural agreement of tea varietals as local classification schemes evolve and group knowledge accumulates; the first eigenvalue accounts for $24.34 \%$ of variance for informants, $48.76 \%$ for males, and a low eigenvalue for female classification schemes.

\section{DISCUSSION}

This study demonstrates that Baljalpuxeevq's Akha have been enterprising in responding to opportunities and limitations provided by the intersection of markets and state policies. Increased market integration and value of 'ecological' tea has heightened the role of tea agroforests in livelihoods and led to a process of decision making resulting in changes in land use, labor, and ecological knowledge. Local Akha have tapped into customary resource institutions and employed collective action to reconfigure land use, reorganize labor structures, and share and negotiate information on tea resources to take advantage of emerging market opportunities. 
Fig. 3. Example of local classification of tea types in Baljalpuxeevq.

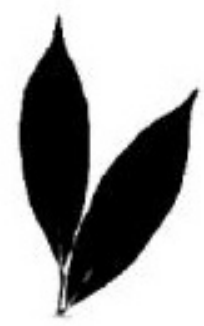

PAVQ QAVL LAOL BAOQ SLENDER LEAF TEA

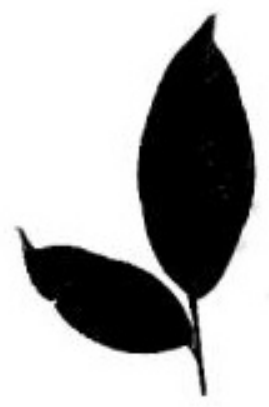

PAVQ MNGL LAOL BAOQ LONG LEAF TEA

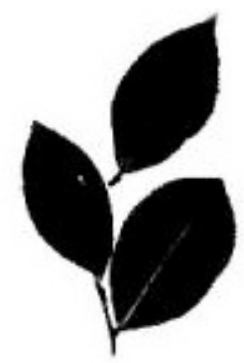

LAOL BAOQ PAVQ MNGL PAVQ NIL LONG LEAF RED TEA

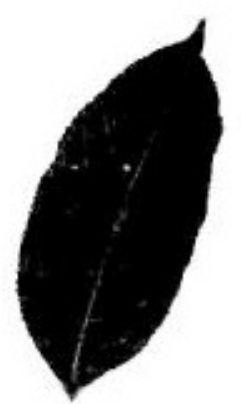

AINI LAOL BAOQ AKHA TEA

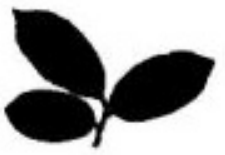

PAVQ SSAQ PAVQ NIL SMALL LEAF RED TEA

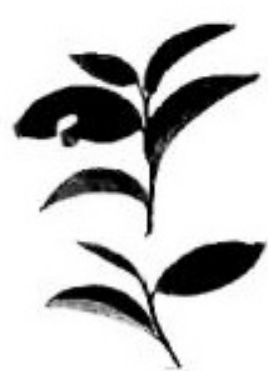

LAVQ BEEQ LAOL BAOQ HAN TEA

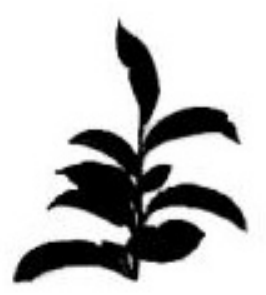

HU QAVQ NAQ PAVP MOUSE EAR TEA

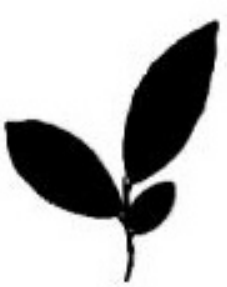

DAL PUL LAOL BAOQ SHRUB TEA
Cooperation with tea industry agents, combined with customary strategies of experimentation, risk management, and the transmission and development of knowledge, has provided a competitive market advantage. These factors have resulted in a distinct situation that both corroborates and diverges from previous studies and highlights the complex nature of the impacts of increased market integration and state development efforts.

Land use simplification during the study period reflects trends of land use and land cover change documented in other communities in southern Yunnan and regionally in response to state projects and globalization (Sturgeon 2005, Xu et al. 2005, Fox 2009, Xu et al. 2009, Zeigler et al. 2009). The cultivation of tea plants in previous swidden areas by the community and private enterprises supports a general trend across Southeast Asia of the transformation of former swidden areas (Mertz et al. 2009) to commercial agriculture and tree farming (Fox et al.2009). However, in contrast to some other communities in the region that have converted their land use to monocultures of cash crops, Baljalpuxeevq's smallholders have maintained a diversified portfolio of subsistence activities to account for market uncertainties. They are cultivating new tea agroforests rather then planting monocultures as in some other communities. The divergent patterns witnessed in Baljalpuxeevq are likely a function of its relative inaccessibility that allowed customary practices to persist. Additionally, its upland location above the altitude where rubber can grow $(1100 \mathrm{~m})$ enabled it to avoid statepromoted rubber projects.

Refined folk taxonomy of tea varietals in response to heightened valuation of tea agroforests and the shift in this agroecological knowledge from women to men points to the complexity and difficulty of 
understanding the impacts of market integration. The generation of agroecological knowledge is valuable from a market perspective because an institution's ability to generate knowledge and create new products is recognized as a source of competitive advantage (Grant 1996). The positive trend of ecological knowledge with increased market integration has been previously documented in a fishing community in Ecuador (Guest 2002) and with new rice landraces under the influence of agricultural modernization in Indonesia (Soemarwoto 2007). However, other studies have found the effects of economic change on traditional ecological knowledge (Godoy et al. 2005) to be negative (Nolan and Robbins 1999, Reyes-Garcia 2001, Zent 2001, Benz et al. 2007, Srithi et al. 2009) or neutral (Zarger and Stepp 2004, Ayantunde et al. 2008). Additionally, as local Akha focus their attention on tea, ecological knowledge of other plants and resources in the community surroundings may be declining.

The increase in agroecological knowledge of tea varietals in Baljalpuxeevq can be attributed to the resourcefulness of local Akha in utilizing customary knowledge and social resources while developing new linkages. The role of customary institutions for resource management in Baljalpuxeevq coincides with previous work on the resilience and importance of customary institutions of the Hani / Akha in the uplands of Xishuangbanna (Xu et al. 1999). The emergence of a market-driven institution in Baljalpuxeevq to organize tea production matches the variables recognized to foster the development of community forestry institutions including: resource salience to livelihoods, manageability of the system, and users' prior organizational experience (Ostrom 1999). In the current context, connections forged with tea industry agents have allowed locals access to market information and enabled sales to national and global high-end niche markets for 'ecological' tea. Social networks within the community, other communities, and with tea industry agents provide a platform for debate on diverse perspectives, sharing and negotiation of information, and articulation of agreed knowledge on tea resources. Social networks also serve to integrate individual knowledge of tea resources and foster the accumulation of group knowledge. The community's open-mindedness norms, cognitive diversity, and recognition of local experts further assist in the development of group knowledge (Mitchell and Nicholas 2006). The interplay of these customary and market factors has allowed the community to enjoy a level of affluence previously unknown and enabled it to endure the recent pu'er tea bust. Figure 4 highlights the process of the development of ecological knowledge of tea resources in response to increased market integration.

The economic benefit of cooperating with tea industry agents is consistent with previous findings in Baljalpuxeevq (Toleno 2006) and more recently in another smallholder community in Xishuangbanna (Menzies 2008). Tea industry agents have had greater success than state programs in integrating consumer demands for high-quality product with local desires to improve livelihoods while maintaining cultural practices and the ecological viability of land use (Toleno 2006). Consumers are willing to pay price premiums for tea from Baljalpuxeevq's agroforests but not from monocultures created for the Grain for Green campaign.

The increased refinement in classification of tea resources supports Berlin's (1992) hypothesis that only species that come under intense human manipulation are further subdivided into folk varietals. Berlin (1992) shows how the degree of linguistic recognition of subgeneric taxa increases as the level of management of plant systems intensifies. The maintenance of local tea types emphasizes the role of cultural preferences in preserving landraces (Brush and Meng 1998) and contributes to Akha cultural identity, as indicated by tea categorized as 'Akha tea' vs. 'Han terrace tea'. More recently, market demand for 'ecological' tea with complex taste profiles contributes to landrace maintenance and is beneficial for cultural continuity and prevention against genetic erosion.

However, as Baljalpuxeevq becomes more accessible with infrastructure development, local value systems and institutions are predicted to continue shifting toward a market orientation. Previous studies on agrarian change suggest potential long-term outcomes of market integration and globalization for rural farming communities, particularly socioeconomic differentiation among rural households. Bernstein (2002) for example argues that socioeconomic unevenness between capitalist farmers and landless laborers is the inevitable long-term outcome of the transition of agriculture to capitalism. He supports that 'marketfriendly' agrarian reforms and other capitalist initiatives do little in the long-term to stimulate 
Fig. 4. The process of ecological knowledge development of tea resources in response increased market integration.

\section{USE OF CUSTOMARY RESOURCES TO MEET MARKET OPPORTUNITIES} FACILITATED BY TEA INDUSTTRY AGENTS

CUSTOMARY
RESOURCES
- Practice of Experimenting with Plants
- Ecological Knowledge
- Management of Tea Agro-Forests
- Customary Institutions
- Experience with Self-Organization

CUSTOMARY RESOURCES

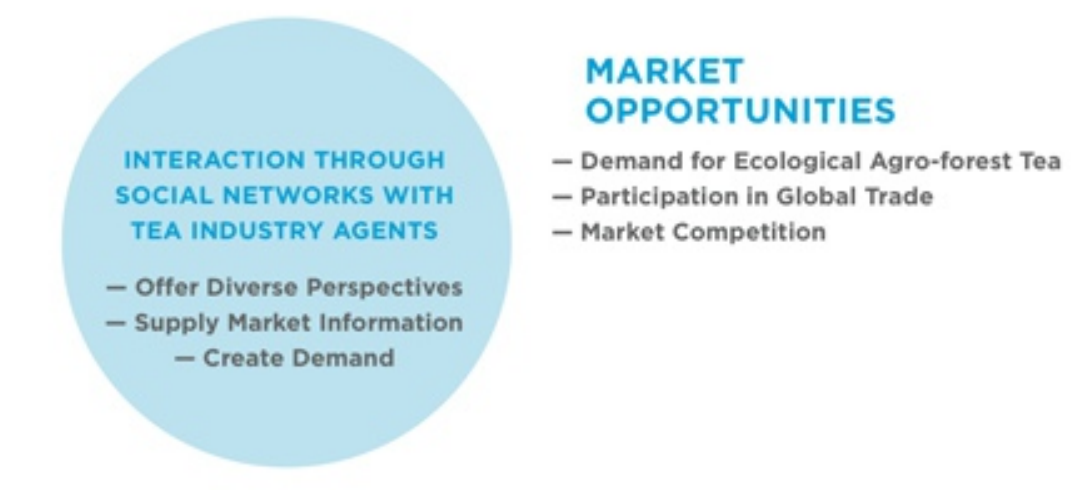

DEVELOPMENT OF ECOLOGICAL KNOWLEDGE AND MARKET INSTITUTIONS

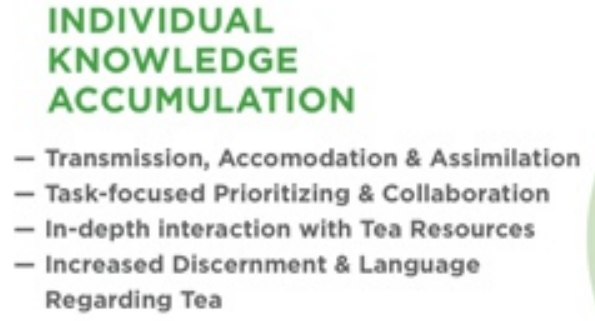

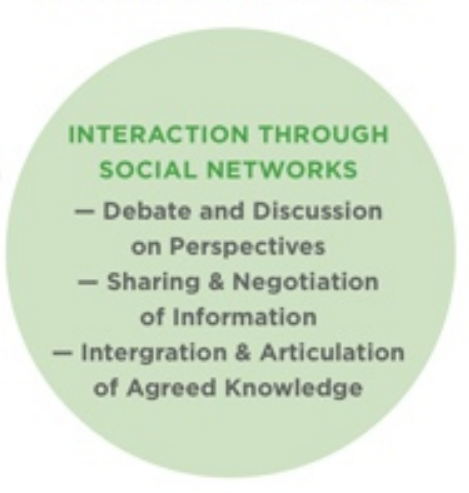

GROUP KNOWLEDGE ACCUMULATION

- Cognitive Diversity of Values \& Knowledge

- Recognition of Local Experts

- Open-mindedness Norms agricultural production and reduce rural poverty. Likewise, Li (2007) contends that social dispossession results from growing capitalist economies. She supports that intervention is necessary to maintain growth of capitalist economies, and that such intervention dispossesses sections of the population. Rigg (2006) highlights that poverty in rural areas is becoming progressively delinked from agricultural resources as nonfarm opportunities expand and increased mobility leads to the delocalization of livelihoods.

The state-facilitated subleasing of village lands to commercial tea enterprises to establish expansive terrace tea plantations is expected to further influence local values and may have adverse environmental and health implications. Run-off from fertilizers, pesticides, and insecticides used by commercial tea enterprises may have negative consequences to surrounding land use, particularly to the village paddy rice fields in the valleys immediately below the new tea terraces and to aquatic fauna in the stream below the village. The tea clones introduced to the uplands by commercial enterprises poses the risk of genetic pollution (Altieri 2003) to the reservoir of tea diversity managed by local communities. The new tea enterprises are able to benefit from the environment that upland groups have managed for hundreds of years, and from the esteemed 'ecological' labels and terroir of the Bulang Mountains that locals have branded. The influx of hundreds of lowland migrant 
laborers presents additional socioeconomic and environmental implications. These laborers are generally not familiar with local ecology and developed their conceptions of nature elsewhere. Atran et al. (1999) show how the cognitive models of ecological relationships held by immigrant populations arriving to a new habitat may be inappropriate to understand the ecology of their new habitat and result in environmental degradation. The environmental consequences of lowland migrant laborers working in the new upland tea enterprises may ultimately damage the 'ecological' branding of Bulang Mountain tea.

\section{CONCLUSIONS}

Despite dramatic change occurring throughout China because of rapid economic growth, this study provides one example of how such growth can have unintended and surprising consequences. Market expansion has led to development in ecological knowledge and institutions associated with tea resources. At the same time, the intense interest in tea production coupled with state discouragement of shifting cultivation has led to changes in land use, most notably away from upland rice and terraced hillside paddy. The large influx of cash into the community has resulted in positive development of a shared community infrastructure, such as road improvements and a new community center. At the household level there has been an increase in consumer goods, many of which would have been considered luxury items a few years before. These dynamics point to the complex nature of social and environmental change and refute simplistic models of market integration and the loss of ecological knowledge. The results clearly indicate a relationship between the perceived value of a commodity and a resulting rise of ecological knowledge and market-driven institutions associated with it. This study provides useful baseline data to examine long-term change associated with market integration and an engagement of ecosystem ecology with anthropology (Abel and Stepp 2003). If the considerable changes occurring in Baljalpuxeevq in the last few years are indicative of broader dynamics, indigenous upland communities in southern Yunnan involved in tea production will likely see substantial social, cultural, economic, and political transformations in the near future. As these communities find their value systems shifting toward market-based economics, what will be the fate of the social institutions that have informed their resource management and livelihood practices?

Responses to this article can be read online at: http://www.ecologyandsociety.org/voll5/iss4/art27/ responses/

\section{Acknowledgments:}

We extend our gratitude to the community of Baljalpuxeevq for hosting this research and sharing their knowledge, experiences, and homes. We are grateful to Professor Long Chunlin and his Research Group for Biodiversity and Plant Resources at the Kunming Institute of Botany and Professor Xue Dayuan at the School of Life and Environmental Sciences at Minzu University for institutional support of our research in China. We appreciate the support of the Environmental Change, Vulnerability and Governance Program at the East-West Center in Honolulu and the institutional affiliation provided during the early phase of this research by Professor Xu Jianchu at the Kunming Institute of Botany. Invaluable guidance and assistance during fieldwork was provided by many people, particularly: Su Yong-Ge, Yang Yahan (Chunyan), and Hu Guang-Wan. We thank Lisa Maoine for her graphic design work. We are thankful to the National Science Foundation (NSF EAPSI OISE-0714431 and NSF DDEP OISE-0749961), Botany in Action Program at Phipps Conservatory, Garden Club of America (Anne S. Chatham Fellowship in Medicinal Botany), East-West Center, and Program 111 of the Chinese Ministry of Education for funding support.

\section{LITERATURE CITED}

Abel, T., and J. R. Stepp. 2003. A new ecosystems ecology for anthropology. Conservation Ecology 7 (3): 12. [online] URL: http://www.consecol.org/vol7/ iss3/art12/.

Ahmed, S., U. Unachukwu, J. R. Stepp, C. M. Peters, L. Chunlin, E. Kennelly. 2010. Pu-erh tea tasting in Yunnan, China: correlation of drinkers' perceptions to phytochemistry. Journal of Ethnopharmacology 132:176-185. 
Alcamo, J., and E. Bennett. 2003. Ecosystems and human well-being: a framework for assessment. Island Press, Washington, D.C., USA.

Altieri, M. A. 2003. The sociocultural and food security impacts of genetic pollution via transgenic crops of traditional varieties in Latin American centers of peasant agriculture. Bulletin of Science, Technology \& Society 23:350-359.

Alting von Geusau, L. 2000. Akha internal history: marginalization and the ethnic alliance system. Pages 122-158 in A. Turton, editor. Civility and savagery. Curran Publishing House, London, UK.

Alting von Geusau, L. 2003. Akha / Yunnanese Chinese symbiosis and strategic identity in southeast Asian mountainous border regions. ThaiYunnan Project Bulletin 5:2-6.

Atran, S., D. Medin, N. Ross, E. Lynch, J. Coley, E.U.Ek, and V. Vapnarsky. 1999. Folkecology and commons management in the Maya lowlands. Proceedings of the National Academy of Sciences 96:7598-7603.

Ayantunde, A., M. Briejer, P. Hiernaux, H. Udo, and R. Tabo. 2008. Botanical knowledge and its differentiation by age, gender and ethnicity in Southwestern Niger. Human Ecology 36:881-889.

Benz, B., H. Perales, and S. Brush. 2007. Tzeltal and Tzotzil farmer knowledge and maize diversity in Chiapas, Mexico. Current Anthropology 48:289-300.

Berlin, B. 1992. Ethnobiological classification: principles of categorization of plants and animals in traditional societies. Princeton University Press, Princeton, New Jersey, USA.

Bernstein, H. 2002. Land reform: taking a long(er) view. Journal of Agrarian Change 2(4):433-463.

Brush, S., and E. Meng. 1998. Farmers' valuation and conservation of crop genetic resources. Genetic Resources and Crop Evolution 45:139-150.

Chen, J., P. Wang, Y. Xia, M. Xu, and S. Pei. 2005. Genetic diversity and differentiation of Camellia sinensis L. (cultivated tea) and its wild relatives in Yunnan province of China, revealed by morphology, biochemistry and allozyme studies. Genetic Resources and Crop Evolution 52:41-52.

Dijk, P., P. Ashton, and J. Ma. 1999. Indo-Burma. Pages 319-334 in R. A. Mittermeier, N. Myers, P. Robles-Gil, and C.G. Mittermeier, editors. Hotspots. CEMEX, Mexico City, Mexico.

Ellen, R., and H. Harris. 2000. Introduction. In R. F. Ellen, P. Parkes, and A. Bicker, editors. Indigenous environmental knowledge and its manifestations: critical anthropological perspectives. Harwood, Amsterdam, The Netherlands.

Fox, J. 2009. Crossing borders, changing landscapes: land-use dynamics in the Golden Triangle. Asia Pacific Issues: Analysis from the East-West Center 92:1-8.

Fox, J., Y. Fujita, D. Ngidang, N. Peluso, L. Potter, N. Sakuntaladewi, J. Sturgeon, and D. Thomas. 2009. Policies, political-economy, and swidden in Southeast Asia. Human Ecology 37:305-322.

Godoy, R., V. Reyes-García, E. Byron, W. Leonard, and V. Vadez. 2005. The effect of market economies on the well-being of indigenous peoples and on their use of natural resources. Annual Review of Anthropology 34:121-138.

Grant, R. M. 1996. Prospering in dynamicallycompetitive environments: organizational capability as knowledge integration. Organization Science 7:375-83.

Guest, G. 2002. Market integration and the distribution of ecological knowledge within an Ecuadorian fishing community. Journal of Ecological Anthropology 6:38-49.

Han, W. Y., F. J. Zhao, Y. Z. Shi, L. F. Ma, and J. Y. Ruan. 2006. Scale and causes of lead contamination in Chinese tea. Environmental Pollution 139: 125-132.

Harlan, J. 1975. Our vanishing genetic resources. Science 188:618-621.

Hill,A. M. 1998. Merchants and migrants: ethnicity and trade among Yunnanese Chinese in Southeast Asia. Yale University Southeast Asia Studies Monograph 47, New Haven, Connecticut, USA. 
Huang, G. 2005. An overview of pu'er tea culture. Yunnan Min Zu Chu Ban She, Kunming, China.

Hunn, E. 1993. What is traditional ecological knowledge? Pages 13-15 in N. Williams and G. Baines, editors. Traditional environmental knowledge: wisdom for sustainable development. Center for Resource and Environmental Studies, Australian National University, Canberra, Australia.

Jarvis, D., C. Padoch, and H. Cooper. 2007. Managing biodiversity in agricultural ecosystems. Columbia University Press, New York, New York, USA.

Jiang, J. 2003. Keji lingxian: quan shehui gouchu shipin anquan wang: wei yiri sancan jie you [Leading technology: the whole society constructs a food safety-net: for the resolving of worries three meals per day]. Renmin Ri Bao [The People's Daily, Science Weekly], Eighth Edition: 10 January 2003.

Kellert, S. R., and E. O. Wilson. 1993. The biophilia hypothesis. Island Press, Washington, D. C., USA.

Li, T. M. 2007. The will to improve: governmentality, development, and the practice of politics. Duke University Press, Durham, North Carolina, USA.

Li, X. W., and D. Walker. 1986. The plant geography of Yunnan Province, southwest China. Journal of Biogeography 13:367-397.

Long, C., Y. Li, and J. Wang. 1997. Traditional tea-garden systems in Xishuangbanna. Pages 70-76 in $\mathrm{S}$. Pei and J. Xu, editors. Biodiversity in swidden agroecosystems in Xishuangbanna. Yunnan Education Press, Kunming, China.

Long, C., and J. Wang. 1996. Studies of traditional tea-gardens of Jinuo nationality, China. Pages 339-344 in S. K. Jain, editor. Ethnobiology in human welfare. Deep Publications, New Delhi, India.

Luo, J., C. Long, and Y. Zhou. 2001. Ecological environment and introduction experiment of several wild tea species from Yunnan. Journal of Wuhan Botanical Research 19(1):79-86.

Menzies, N. 2008. Ancient forest tea: how globalization turned backward minorities into green marketing innovators. Social Life of Forests Conference 30-31 May 2008, University of Chicago, Chicago, Illinois, USA.

Mertz, O., C. Padoch, J. Fox, R. A. Cramb, S. J. Leisz, N. T. Lam, and T. D. Vien. 2009. Swidden change in Southeast Asia: understanding causes and consequences. Human Ecology 37:259-264.

Ming, T. 1992. A revision of Camellia sect. Thea. Acta Botanica Yunnanica 14(2):115-132.

Ming, T., and W. Zhang. 1996. The evolution and distribution of genus Camellia. Acta Botanica Yunnanica 18:1-13.

Mitchell, R., and S. Nicholas. 2006. Knowledge creation in groups: the value of cognitive diversity, transactive memory, and open-mindedness norms. The Electronic Journal of Knowledge Management 4(1):67-74.

Nolan, J. M., and M. C. Robbins. 1999. Cultural conservation of medicinal plant use in the Ozarks. Human Organization 58:67-72.

Ostrom, E. 1999. Self-governance and forest resources. Center for International Forestry Research Occasional Paper 20:1-15.

Qin, F., and W. Chen. 2007. Lead and copper levels in tea samples marketed in Beijing, China. Bulletin of Environmental Contamination Toxicology 79:247-250.

Reyes-Garcia, V. 2001. Indigenous people, ethnobotanical knowledge, and market economy: a case study of the Tsimane' Amerindians of lowland Bolivia. Dissertation, University of Florida, Gainesville, Florida, USA.

Rigg, J. 2006. Land, farming, livelihoods, and poverty: rethinking the links in the rural south. World Development 34:180-202.

Rocha, J. 2005. Measuring traditional agroecological knowledge: an example from peasants in the Peruvian Andes. Field Methods 4:356-372.

Schendel, W. 2001. Geographies of knowing, geographies of ignorance: jumping scale in Southeast Asia. In P. Kratoska, R. Raben, and H. Nordholt, editors. Locating Southeast Asia: geographies of knowledge and politics of space. 
Singapore University Press, Singapore, Republic of Singapore.

Scott, J. 2009. The art of not being governed: an anarchist history of upland Southeast Asia. Yale University Press, New Haven, Connecticut, USA.

Soemarwoto, R. 2007. Kaepuhun rice landrace diversity, risk management and agricultural modernization. In R. Ellen, editor. Modern crisis and traditional strategies: local ecological knowledge in island Southeast Asia. Berghahn Books, New York, New York, USA.

Srithi, K., H. Balslev, P. Wangpakapattanawonga, P. Srisangac, and C. Trisonthi. 2009. Medicinal plant knowledge an its erosion among the Mien (Yao) in northern Thailand. Journal of Ethnopharmacology 132:335-342.

Stepp, J. R., H. Castaneda, and S. Cervone. 2005. Mountains and biocultural diversity. Mountain Research and Development 25(3):223-27.

Sturgeon, J. 2005. Tea for trees: the impact of state policies on the Akha in Yunnan. Indigenous Affairs 2(5):36-42.

Sturgeon, J. 2007. Pathways of "indigenous knowledge" in Yunnan, China. Alternatives: Global, Local, Political 32(1):129-139.

Toleno, R. 2006. A critical ecology of Akha tea cultivation in the Bulang Mountains of China: the case of Buljalpuxeevq. Thesis, University of Hawaii, Honolulu, Hawaii, USA.

Turrill, W. 1926. Studies on the origins of cultivated plants. Nature 2967(118):392-393.

Wang, Z. 2005. Chaye chengpin hanyan chaobiao 35 bei: ducha shijian yangji Guizhou wuxing chanong [Lead content of tea leaf commodities exceeds standard by 35 times: the poison tea incident spreads disaster to Guizhou's innocent tea farmers]. Renmin Ri Bao [The People's Daily, View Point News] Fifth Edition: 10 June 2005.

Weller, S., and A. Romney. 1988. Systematic data collection. Sage Publications, Newbury Park, California, USA.

Xiao, P. G., and Z. Y. Li. 2002. Botanical classification of tea plants. Pages 17-34 in Y.S.
Zhen. Tea: bioactivity and therapeutic potential. Medicinal and aromatic plants - industrial profiles. Taylor and Francis, London, UK.

Xu, J., J. Fox, L. Xing, N. Podger, S. Leisz, and A. Xihui. 1999. Effects of swidden cultivation, state policies, and customary institutions on land cover in a Hani village, Yunnan, China. Mountain Research and Development 19(2):123-132.

Xu, J., J. Fox, P. Zhang, Y. Fu, L. Yang, J. Qian, S. Leisz, and J.B. Vogler. 2005. Land-use and landcover change and farmer vulnerability in Xishuangbanna prefecture in southwestern China. Environmental Management 36(3):404-413.

Xu, J., L. Lebel, J. Sturgeon. 2009. Functional links between biodiversity, livelihoods, and culture in a Hani swidden landscape. Ecology and Society 14(2): 20. [online] URL: http://www.ecologyandso ciety.org/vol14/iss2/art20/.

Xu, Z., J. Xu, X. Deng, J. Huang, E. Uchida, S. Rozelle. 2006. Grain for green versus grain: conflict between food security and conservation set-aside in China. World Development 34(1):130-148.

Yang, B. 2004. Horses, silver and cowries: Yunnan in global perspective. Journal of World History 15 (3):281-322.

Zarger, R. K., and J. R. Stepp. 2004. Persistence of botanical knowledge among Tzeltal Maya children. Current Anthropology 45:413-418.

Zent, S. 2001. Acculturation and ethnobotanical knowledge loss among the Pairoa of Venezuela: demonstration of a quantitative method for the empirical study of TEK change. Pages 190-211 in L. Maffi, editor. On biocultural diversity: linking language, knowledge, and the environment. Smithsonian Institution Press, Washington, D.C., USA.

Ziegler, A., J. Fox, and J. Xu. 2009. The rubber juggernaut. Science 324:1024-1025. 